\title{
Uses, Abundance Perception and Potential Geographical Distribution of Smilax Aristolochiifolia Mill (SMILACACEAE) on the Totonacapan Region of Puebla, Mexico
}

José Espinoza-Pérez ( $\square$ jose.espinoza@estudianteposgrado.ecosur.mx )

El Colegio De La Frontera Sur - Unidad San Cristóbal: El Colegio de la Frontera Sur https://orcid.org/0000-0002-4274-5014

César Reyes

Universidad Intercultural del Estado de Puebla

Jesús Hernández-Ruíz

Universidad de Guanajuato

Maximino Díaz-Bautista

Universidad Intercultural del Estado de Puebla

Francisco Ramos-López

Universidad Intercultural del Estado de Puebla

Abel Espinoza-Gómez

Universidad Intercultural del Estado de Puebla

\section{Research Article}

Keywords: Abundance, Ethnobotanic, Potential distribution, Use Value, Wild edible plants

Posted Date: February 19th, 2021

DOI: https://doi.org/10.21203/rs.3.rs-211468/v1

License: (c) (i) This work is licensed under a Creative Commons Attribution 4.0 International License. Read Full License 


\section{Abstract}

\section{Background}

Edible wild plants have been displaced or eliminated from the traditional production systems in Mexico, mainly by the changes in land use, monoculture booming, and by changes in the traditional foods and diets of the new generations of indigenous populations. One of the millennial species which has been used in traditional medicine and food recipes by Mesoamerican cultures is Smilax aristolochiifolia (SMILACACEAE), known by the Totonac culture as "Kgentsililh". These species are part of traditional Totonac recipes where the tender stems are still used in local medicine to treat menstrual pain, to deal with dysentery, and to prevent hair loss. This current ethnobotany and ecological investigation recorded the abundance perception and use value as a food diet ingredient and traditional medicine in the context of Totonac culture families and further estimation of the potential geographical distribution of $S$. aristolochiifolia in the State of Puebla, Mexico.

\section{Methods}

Were applied to 260 interviews in 13 locations in the northern Sierra of the State of Puebla. Variables taken into account in the interview have related to the consumption frequency of the species, abundance perception, reasons, or arguments by the indigenous population about the decrease presence of specimens of $S$. aristolochiifolia, dates of collection, cutting prices of Kgentsililh at a community level and local markets. The relative abundance of $S$. aristolochiifolia determined through 22 samples in quadrants of 500 $\mathrm{m}^{2}$, later, was estimated the potential distribution in the state of Puebla by using the Maxent Program ${ }^{\circledR}$ Ver. 3.3.3.

Results

From 260 interviews, 82 indigenous families stopped consuming Kgentsililh in the last two years, and consumption frequency decreased to once by a year, and there were no significant differences between communities. In traditional medicine, the stem sap of $S$. aristolochiifolia currently employed to help treat baldness, and from the sweet potato to prepare a tea infusion to treat dysentery. All persons interviewed argued that the main reason leading to an overall decline of species are: changes in land use, herbicide applications, especially on coffee plantations and milpa agroecosystems, climate change, overcollection of the species, and the increase of the urban stain. The average cost of plant guides varies from 10.00 to 40.00 Mexican pesos by one bunch (around 0.5 to 1.8 USD dollars). From all 22 locations of sampling and collection of $S$. aristolochiifolia, we were able to recognize a total of 32 specimens. The highest abundance was recorded on acahual agroecosystems with a specimen presence value of 1.8 , and milpa with a value of 1.0. According to our analysis on the Maxent Program ${ }^{\circledR}$, eight physical and climatic variables have a direct relationship in the potential distribution of the species.

Conclusions 
Smilax aristolochiifolia remains as a species of socio-economic importance among Totonac culture within the state of Puebla, mainly by concerning food issues but not in medicinal items. There is a low

abundance of specimens of the species since of the collective perspective of indigenous people, provoked by changes in land use, herbicide applications on different units of production, and climate change. Ecological evidence shows that in $\mathbf{3 7}$ municipalities of northern of the state of Puebla, there are potential areas with suitable habitat to take conservation programs in situ of $S$. aristolochiifolia.

\section{Introduction}

In Mexico, according to the ethnobotanical database of Mexican Plants (DATEPLAM), there are reported 7,647 plant species considered as a useful species, from which 2,168 are edible and can have encountered as wild, domesticated, weeds, or ruderal plants [1] with many different ways of management [2,3]. Herein, most of the wild edible plants collected represent around $15 \%$ of the diet ingredients of the indigenous rural Mexican population [4], despite having been domesticated about $65 \%$ of all country plant species diversity $[5,6]$. However, several influential factors allow a latent risk of loss of edible wild plants, such as changes in the land use [7], deforestation of jungles and wood forests [8, 9], climate change [10], and their use as an ingredient on agri-food industry $[11,12]$, besides to the loss of traditional knowledge by indigenous people as a background agrobiodiversity knowledge.

One of the most common methods to know the conservation status, management, and the use of edible wild plants is through the study of the complex kosmos-corpus-praxis and by the analysis of cosmovision of human groups. The conclusions of such studies indicate the richness of their vegetable world and make known the close relationship between indigenous people at the species level $[13,14]$. It is well-known and documented that indigenous people maintain a close relationship with wild edible plants and give them value according to their social, economic, and ecological importance $[15,16,17,18]$. Likewise, it is also to take into account the influence of anthropogenic factors on the state of conservation, presence, and distribution of wild edible species. Therefore, it is necessary for the revision of some formal investigations which have reported the use of statistical spatial models of plant distribution and have demonstrated its value as a useful tool $[19,20]$. The identification of suitable habitats for the proliferation of a particular species could result in the discernment of subtle physical changes that could affect their geographical potential distribution area [21].

In this context, several authors have reported the use of Bioclim and Maxent statistical models allowing the estimation of the geographical spatial distribution of wild species such as Jefea genus (Asteraceae) [22], Agave potatorum [23], Prosopis flexuosa [24], Vanilla planifolia [25], and Carica papaya [26]. However, Maxent model is so far the most confident for the analysis of the spatial distribution of a particular species because it does not take into account sampling bias. Therefore, it is possible to predict their geographical distribution by adding physical parameter data together with specific and supplemented plant data with some predictable continuous and categorical variables [27, 28].

One of the wild millennial Mesoamerican plant species which have been widely exploited as a food ingredient and used in traditional medicine is Smilax aristolochiifolia [29, 30, 31]. S. aristolochiifolia is a 
perennial woody climber, native from Mexico and Central America and its actual distribution comprises Costa Rica, Guatemala, Belize, and Mexico [32]. Within a Mexican land territory, S. aristolochiifolia distributes in the states of Chiapas, Campeche, Tabasco, Oaxaca, San Luis Potosí, Tamaulipas [32], Puebla [30], and Veracruz [33].

In the state of Puebla, S. aristolochiifolia distributes along the northern and northwest Sierra of Puebla. In this region, tender stems of the plant are used as a food ingredient of local recipes and used to treat certain diseases and medical conditions; herein, indigenous Totonaca and Nahua cultures use the plant to treat menstrual pain and dysentery [31]. In this region, S. aristolochiifolia inhabits tropical forest, acahual (a type of traditional agroecosystem with local secondary vegetation), and coffee plantations, mainly in the municipalities of Tuzamapan de Galeana, Zapotitlán de Méndez, Cuetzalan del Progreso, and Xochitlán de Vicente Suárez [30, 31]. Despite their importance, according to previous reports obtained from four data collections in the study area, the geographical distribution of $S$. aristolochiifolia had significantly declined.

Due to the above, the current research departs from the next research questions:

- What could be the potential geographical distribution of aristolochiifolia in the state of Puebla?

- What are the main physical and climatic features that determine their geographical distribution?

- What is the general perception of indigenous people about the relative species abundance?

- What are the main reasons that indigenous people perceive an abundance decrease of S. aristolochiifolia?

The first hypothesis is: The main parameters that affect the distribution of $S$. aristolochiifolia are related to physical climate variables such as altitude and rainfall patterns. This formulation is because the plant grows in secondary forest vegetation (acahual type agroecosystems), coffee plantations, and primary vegetation (evergreen lowland forest).

The second hypothesis that arises here is: $S$. aristolochiifolia still maintains its food and medicinal value, despite their relatively low abundance perception by indigenous people, and this phenomenon is a consequence of changes in land use, herbicide applications, and its overexploitation.

\section{Materials And Methods}

\section{Background knowledge}

Smilacaceae family belongs to the Monocot family of lianas, shrubs, and herbs, which are widely distributed in tropical and subtropical ecosystems but also inhabit temperate zones located on the northern and southern hemispheres of Earth [34]. Based on previous floristic and monographic studies, which describe around 350 different species of Smilacaceae family, nevertheless, Ferrufino-Acosta [32], Li [35], and Govaerts [36] argue that at least $40 \%$ of total species described is purely related simply to synonyms. It means that only 210 species of Smilacaceae family could be recognized [31]. Central and 
South America reported that Smilax genus consists approximately of 260 species (including synonyms) [37] where only 28 are endogamy species of Mexico [38]. One of those species is S. aristolichiifolia Mill., which is a wild species, and found commonly in the wet tropical forests of Mexico between 100 to 800 meters above sea level $[32,39]$. Studies performed in this country reported specific details of the habitat of S. aristolochiifolia, and its distribution comprises humid and sub-humid tropical regions from 15 to 800 meters above sea level [32, 33]. By contrast, Ruíz-Sánchez et al. [40] reported a creeper specimen on coniferous forest between 2,200 to 2,724 meters above sea level in the State of Durango; according to the authors, it may be considered as a humidity index indicator. The growth of species in such environmental conditions has been reporting in eight states of Mexican territory [30, 32, 33].

\section{Study area}

The Totonacapan region comprises the northern part of the State of Puebla, which has a high cultural and biological importance in Mexico [41, 42]. Several authors reported around 600 useful plant species used mainly as food, medicinal and ornamental issues, but is also known for other 20 different uses [31]. Around 200 plant species are used as a food ingredient and employed in indigenous traditional food recipes, which grow on coffee plantations, family gardens, traditional milpas, acahual agroecosystems, chilies, and beans plantations. The local plant biodiversity is a result of agricultural practices such as the slash and burn method [30,43-46]. It is well-known that the subsistence alimentary strategy of the Totonac communities depends broadly on the utilization of a great diversity of useful plants, including wild, tolerated, and cultivated species [31, 47] where the corn crop plays a key role [48].

The study took place in 13 locations of the Totonacapan region of Puebla. These localities have previously reported the presence of $S$. aristolochiifolia [31], and we include new sites where local people reported sightings of the plant in determining communities. All the target sites are distributed in environments with hot and humid climate $A(f)$ and semi-warm humid $(A) C(f m)$ at altitudes from 250 to 1360 meters above sea level (Table 1).

\section{Table 1. Description of study locations}




\begin{tabular}{|llll|}
\hline Community & Municipalities & Altitude (m.a.s.l.) & Climate \\
\hline Ozelonacaxtla & Huehuetla & 850 & A(f) \\
\hline San Rafael & Ixtepec & 500 & A(f) \\
\hline Tetelilla & Tuzamapan & 540 & A(f) \\
\hline Tzinacapan & Cuetzalan & 850 & A(f) \\
\hline Ayotzinapan & Cuetzalan & 582 & A(f) \\
\hline Cucuchuchut & Caxhuacan & 390 & A(f) \\
\hline Caxhuacan & Caxhuacan & 705 & A(f) \\
\hline Zoquiapan & Zoquiapan & 1010 & $(\mathrm{~A}) \mathrm{C}(\mathrm{fm})$ \\
\hline Olintla & Olintla & 541 & $\mathrm{~A}(\mathrm{f})$ \\
\hline Atlequizayan & Atlequizayan & 830 & $\mathrm{~A}(\mathrm{f})$ \\
\hline Tuxtla & Zapotitlán de Méndez & 820 & $\mathrm{~A}(\mathrm{f})$ \\
\hline Tapayula & Camocuautla & 1200 & $(\mathrm{~A}) \mathrm{C}(\mathrm{fm})$ \\
\hline Cuautotola & Amixtlán & 1360 & $(\mathrm{~A}) \mathrm{C}(\mathrm{fm})$ \\
\hline
\end{tabular}

\section{Ethnobotanical evidence}

Were performed 260 survey applications designed for rural indigenous people, which belong to 13 different municipalities (Table 1). At the field level, during the collection of specimens of $S$. aristolochiifolia, every target site was georeferenced and recorded in the field. Applied surveys considered the next questions (variables): consumption frequency, use in traditional medicine, abundance perception, convincing arguments about the geographical area reduction of specimens, harvesting dates and cutting community, and local market prices. Besides, in every survey application was considered an additional section to collect gastronomic and medicinal traditional protocols related to $S$. aristolochiifolia.

\section{Distribution modeling, abundance, and identification of S. aristolochiifolia}

Between 2019 to 2020 were located 13 different communities where S. aristolochiifolia usually grows by using the method known as "hiking through the forest" $[23,49]$ during the harvest months (March, April, and September), including the flowering stage in November. Plant abundance in plantations determined through 22 samples obtained from quadrants of $500 \mathrm{~m}^{2}$ of milpas agroecosystems, coffee plantations, acahual, and primary vegetation. Every collection of specimens was georeferenced with a Global Positioning System (GPS Garmin Etrex 32x $®$ ). During the examination were identified in situ thirty-two individuals distributed into 22 quadrants.

Later, we estimated the geographical spatial distribution and habitat suitability by using Maxent Program Ver. 3.3.3 [50, 51]. To carry out the analysis, we used 22 variables as a predictor (Table 2), from which 19 
were bioclimatic variables of high spatial resolution ( 0.5 arc minutes); this gets downloaded from the database WorldClim (worldclim.org). Also were considered three environmental data: 1) Digital Terrain Elevation Data (DEM; 30 m of resolution), which has been obtained from the geographical elevation continuum of Mexico 3.0 [52], 2) Shells "shapefile" of usable land and vegetation existing in Mexico [53], and 3) Soil moisture regime [54].

Table 2. Environmental and bioclimatic variables used to assess the geographical potential distribution area of $S$. aristolochiifolia in the State of Puebla, Mexico.

\begin{tabular}{|lll|}
\hline Code & Variable description & Units \\
\hline Bio1 & Average annual temperature & ${ }^{\circ} \mathrm{C}$ \\
\hline Bio2 & Diurnal temperature oscillation & ${ }^{\circ} \mathrm{C}$ \\
\hline Bio3 & Isothermality & Dimensionless \\
\hline Bio4 & Temperature seasonality & $\mathrm{CV}$ \\
\hline Bio5 & Average maximum temperature of the warmest period & ${ }^{\circ} \mathrm{C}$ \\
\hline Bio6 & Average minimum temperature of the coldest period & ${ }^{\circ} \mathrm{C}$ \\
\hline Bio7 & Annual temperature oscillation & ${ }^{\circ} \mathrm{C}$ \\
\hline Bio8 & Average temperature of the rainiest four-month period & ${ }^{\circ} \mathrm{C}$ \\
\hline Bio9 & Average temperature of the driest four-month period & ${ }^{\circ} \mathrm{C}$ \\
\hline Bio10 & Average temperature of the warmest quarter & ${ }^{\circ} \mathrm{C}$ \\
\hline Bio11 & Average temperature of the coldest quarter & ${ }^{\circ} \mathrm{C}$ \\
\hline Bio12 & Annual precipitation & $\mathrm{mm}$ \\
\hline Bio13 & Precipitation of the rainiest period & $\mathrm{mm}$ \\
\hline Bio14 & Precipitation of the driest period & $\mathrm{mm}$ \\
\hline Bio15 & Seasonality of precipitation & $\mathrm{mm}$ \\
\hline Bio16 & Precipitation of the wettest four-month period & $\mathrm{mm}$ \\
\hline Bio17 & Precipitation of the driest four-month period & $\mathrm{mm}$ \\
\hline Bio18 & Precipitation of the hottest quarter & $\mathrm{mm}$ \\
\hline Bio19 & Coldest quarter precipitation & $\mathrm{mm}$ \\
\hline Bio20 & Altitude & $\mathrm{mm}$ \\
\hline Bio21 & Humidity regime & types \\
\hline Bio22 & Ground cover & \\
\hline
\end{tabular}


$\mathrm{C}=$ degree Celsius, $\mathrm{CV}=$ coefficient of variation; $\mathrm{m}=$ meters; $\mathrm{mm}=$ millimetres

\section{Data analysis and description of potential geographical areas of distribution}

Data analysis was performed with non-parametric and parametric tests using the SPSS statistical package V.20.0.0.0. First, the consumption frequency of $S$. aristolochiifolia converted to a normality test. From here, we determined the existence of significant differences among the consumption frequency of Kgentsililh between the 13 locations by using the Kruskal-Wallis test $(p<0.05)$. Also was performed a Chi-squared test to determine the independence between data abundance perception and associated factors related to the abundance of $S$. aristolochiifolia.

Finally, by using the Maxent Program were obtained Gradient File layers of potential distribution area based on field data. Layers exported to ArcMap Program Ver. 10.3 (2018), and were converted to a vector format to estimate the potential geographical area distribution of $S$. aristolochiifolia.

\section{Results}

\section{Ethnobotany}

\section{Origin of the name of the species}

S. aristolochiifolia is well known as "Kgentsililh" or "Kgantsililh" depending on the variant of the Totonac language. Therefore, such a name is a compound word which derived from Kgen/Kgan and Tsililh, and in English could be translated as "dark shrimp nose". This name comes from their close resemblance that exists between the apical part of the $S$. aristolochiifolia with the antennae of dark shrimp (Macrobrachium acanthurus) and therefore (Figure 1a), in Spanish, the species are also known as "bigotes de camalla", "cosole" or "zarsaparrilla" [55].

\section{Abundance perception}

S. aristolochiifolia is a species with high socioeconomic importance, and some families earn revenues from the cuttings commercialization (Figure 1b), therefore have relevance as a culinary item. Every day, this plant diminished its populations in the northern Sierra of the State of Puebla. According to indigenous families, this phenomenon occurs by several factors such as land change use, herbicide applications on milpas and coffee plantations, climate change, over-collection, urban sprawl growth of municipal seats overtaking natural surroundings of tropical and wood forest.

From 260 people interviewed in 13 communities, data obtained about abundance perceptions of $S$. aristolochiifolia showed that: Kgentsililh abundance diminished with the time, where 156 people considered it as a low abundance species. This people's perception, according to the results of the $\mathrm{Chi}^{2}$ test, there is a relationship between associated factors with a population decrease of $S$. aristolochiifolia (Table 3). In this case, the relatively low abundance is associated, according to the interviewed people, with 
the application frequency of herbicides, land change use, and climate change. The last factors have been identified across the year by the pluvial patterns and temperature average rise (Table 3 ).

\section{Table 3. Abundance perception concerning the factors associated with the reduction presence of $S$. aristolochiifolia in the northern Sierra of State of Puebla.}

\begin{tabular}{|c|c|c|c|c|}
\hline \multirow[t]{2}{*}{$\begin{array}{l}\text { Factors associated with abundance reduction of } \\
\text { the specie }\end{array}$} & \multicolumn{3}{|c|}{$\begin{array}{l}\text { What is your perception of species } \\
\text { abundance? }\end{array}$} & \multirow[t]{2}{*}{ Total } \\
\hline & Low & Medium & High & \\
\hline Change use of land & 39 & 11 & 9 & 59 \\
\hline Herbicides applications & 83 & 37 & 1 & 121 \\
\hline Climate change & 26 & 9 & 13 & 48 \\
\hline Over collection & 7 & 11 & 6 & 24 \\
\hline Increase of the urban sprawl & 1 & 2 & 5 & 8 \\
\hline Total & 156 & 70 & 34 & 260 \\
\hline
\end{tabular}

$\mathrm{Chi}^{2}=54.285, \mathrm{gl}=8, \mathrm{p}=0.000$

\section{Nutritional and medicinal use}

As an alimentary issue, this study demonstrated that $S$. aristolochiifolia is consumed during most of the year by indigenous people. Despite this, 82 of 260 people interviewed argued that they have not considered Kgentsililh or stopped eating it in their diet since two years ago. The consumption frequency varies from 1 to 2 times by year (Figure 2), although the global median is near to once a year.

Within indigenous communities, the results showed the same consumption pattern of Kgentsililh as we can see, were no significant statistical differences between them ( $p$ > 0.417$)$. Indigenous families argued that the main reasons for low rate consumption of $S$. aristolochiifolia could be to the next factors: a) low availability of the plant, b) changes in traditional dietary patterns of new generations, and c) lack of knowledge about local culinary recipes. As a food source, we found three different recipes to prepare $S$. aristolochiifolia: a) "Enchiladas" which consists of cut into slices of $5 \mathrm{~cm}$ approximately the plant guide and boiled with epazote leaves and pieces of serrano chili or chiltepin chili (Figure 3); b) As an ingredient, consists on the cook of the guide in boiled water with the addition of corn dough and beans; and c) Chilpozo, which consists in adding slices of $S$. aristolochiifolia to boiled dark shrimp.

In traditional medicine, according to the results of this investigation, Totonac people reported that $S$. aristolochiifolia used to treat baldness and stomach pain. In the first case, a tender guide plant is cutting, and the sap is extracted and spread over the head; this process is used on women who gave birth and on children that their hair cannot grow. For the second treatment, people obtained an extract called "sweet potato" from the roots of $S$. aristolochiifolia, and then it is washed and dried to prepare a tea infusion. On 
average, are used around 100 grams of crushed sweet potato of S. aristolochiifolia by a liter of boiled water (Figure 5).

\section{Economic importance}

Concerning the economic issue, the average cost of plant guides varies from 10.00 to 20.00 Mexican pesos (around 0.45 to 0.9 USD dollars), and every bundle consists of between 7 to 10 cuttings (Figure 1c). On the local market, Kgentsililh is sold as cut lengths of $0.5 \mathrm{~cm}$ approximately and sell only at 5.00 Mexican pesos (0.22 USD dollars). In all communities, there are 3 or 4 committed people to carry out the collection and commercialization of the species. In general terms, there is an income between 120.00 to 470.00 Mexican pesos per year (5.5 to 21.4 USD dollars).

\section{Ecological aspects}

\section{Abundance}

From twenty-two sampling sites, we were able to identify thirty-two specimens of $S$. aristolochiifolia, where acahual and coffee plantations showed an average abundance of 1.85 to 1.0 individuals, respectively (Table 4). It is collected almost through the year, especially during March, April, July, August, September, and October, which correspond to the period of highest abundance (Figure 1b). S. aristolochiifolia is a tolerated species that grow on coffee plantations, acahual, and milpa agroecosystems, but there is no specific interest in improving their production, carrying out clonal reproduction programs, or artificial selection of the species.

Table 4 Features of sampling sites of $S$. aristolochiifolia on the Totonacapan land territory of Puebla.

\begin{tabular}{|c|c|c|c|c|}
\hline Space & $\begin{array}{l}\text { Number of } \\
\text { specimens }\end{array}$ & $\begin{array}{l}\text { Number of } \\
\text { sampling sites }\end{array}$ & $\begin{array}{l}\text { Number of specimens } \\
\text { (average) }\end{array}$ & $\begin{array}{l}\text { Pending site } \\
\text { (average) }\end{array}$ \\
\hline Acahual* & 13 & 7 & 1.85 & $27 \%$ \\
\hline $\begin{array}{l}\text { Coffee } \\
\text { plantations }\end{array}$ & 7 & 6 & 1.16 & $24 \%$ \\
\hline Milpa & 1 & 1 & 1 & $21 \%$ \\
\hline $\begin{array}{l}\text { Primary } \\
\text { vegetation }\end{array}$ & 11 & 8 & 1.37 & $33 \%$ \\
\hline
\end{tabular}

* Abandoned coffee and milpa plantations

\section{Potential distribution of $S$. aristolochiifolia}

Eight of the twenty-two variables (Table 5) used as an abundance predictor model of the potential distribution of $S$. aristolochiifolia contributed significantly to known the most suitable habitat distribution of Kgentsililh, among them precipitation of the driest month (51.7\%), the warmest quarter (38.3\%), and ground cover (3.7\%). Other variables completed the distribution model, such as humidity regime $(2.2 \%)$, 
altitude (1.8\%), annual precipitation (1.4\%), the average temperature of the driest four-month period ( $0.9 \%)$, and rainfall of the driest four-month period $(0.1 \%)$.

\section{Table 5. Percentage contribution of bioclimatic variables in prediction distribution models for $S$. aristolochiifolia of the State of Puebla, Mexico.}

\begin{tabular}{|ll|}
\hline Variable & Percent contribution (\%) \\
\hline Precipitation of the driest period (Bio14) & 51.7 \\
\hline Precipitation of the warmest quarter(Bio18) & 38.3 \\
\hline Ground cover (Bio22) & 3.7 \\
\hline Humidity regime (Bio21) & 2.2 \\
\hline Altitude (Bio20) & 1.8 \\
\hline Annual precipitation (Bio12) & 1.4 \\
\hline Average temperature of the driest four-month period (Bio9) & 0.9 \\
\hline Precipitation of the driest four-month period (Bio17) & 0.1 \\
\hline
\end{tabular}

According to our results, the potential land area distribution of S. aristolochiifolia will cover 37 municipalities of the State of Puebla, where 11 corresponds to this study. The analysis split into three areas: Potential Area I (gray yellow), characterized by a habitat of low quality (Figure 4); this area includes $430.2 \mathrm{~km}^{2}$, which distributes into 24 municipalities. Potential Area II, marked in green color, has $548.5 \mathrm{~km}^{2}$ grouped on 18 communities. The most suitable habitat for the growth of Kgentsililh is in Potential Area III with $574.9 \mathrm{~km}^{2}$, which comprises 21 communities (Figure 4).

Area III corresponds to the highest habitat quality for the species and presents the next features: semiwarm humid climate of $\mathrm{C}$ group, average annual temperature more than $18{ }^{\circ} \mathrm{C}$, and less than $18{ }^{\circ} \mathrm{C}$ of the coldest month, altitude ranging from 285 to 950 meters above sea level. Besides, this area has an annual rainfall between 2,500 to $4,000 \mathrm{~mm}$, the warmer quarter varying between 800 to $1500 \mathrm{~mm}$, and a udic moisture regime level from 330 to 365 days. The characteristic vegetation varies from medium sub deciduous forest to high evergreen forest. It is important to recall that $S$. aristolochiifolia depends widely on the little disturbance of natural vegetation and friendly farming practices for their survival; therefore, the species grows on coffee and acahual plantations and milpa farms.

On the other hand, Area I and Area II have from low to medium habitat qualities and is well characterized by their warm-humid climate, with an average annual temperature greater than $22{ }^{\circ} \mathrm{C}$ and coldest month temperature greater than $18^{\circ} \mathrm{C}$, altitude less than 200 meters above sea level, humidity regime udic between 270 to 330 days. The areas are characterized by their deciduous forest vegetation and land use mainly by monoculture plantations of citrus, banana trees, corn, and apple orchards. 


\section{Discussion}

\section{Use of S. aristolochiifoliain food and medicine}

The use of S. aristolochiifolia as a food ingredient is employed in around $68 \%$ of family homes interviewed, independently of the frequency consumption (Figure 2). On the northern Sierra of the State of Puebla, the tender parts of the stems historically have been prepared according to local indigenous recipes such as roasted, boiled, stewed, or submerged in vinegar like asparagus [30,31]. Without a doubt, the low consumption frequency of $S$. aristolochiifolia by the indigenous people is due to the next factors: introduction of new eating patterns by the new generations, the relatively low abundance of species, and lack of knowledge of traditional recipes. In contemporary Mexico, as occurs in the global context, the agrifood industry has modified the consumer's preferences [11, 12], including the indigenous population [56], therefore, reflects the changes of ingredients of traditional culinary recipes.

In Mexican traditional medicine, the part of $S$. aristolochiifolia most frequently consumed as "sweet potato" is obtained from roots and the sap contained in the stalks. All people interviewed use the tender stems and "sweet potato" to treat baldness and stomach pain, although the study area has also reported the use of the plant to treat menstrual pain and dysentery $[31,57]$. In the state of Queretaro, in Mexico, Otomies and Nahuas cultures use the plant to prepare an oral infusion from "sweet potato" is used to treat obesity [57, 59]. In the case of Chinanteca culture of the state of Oaxaca, Mexico, the people prepare a tea infusion from "sweet potato" to deal with a dermatological disease known as "mal del pinto" [60]. In other regions of Mexico, tea infusion is prepared from "sweet potato" of $S$. aristolochiifolia, and consumed as a blood purifier, treatment against syphilis, diabetes, stomach infections, and seasonal influenza [61, 62].

According to the previous ethnobotanical reports, some relevant facts about traditional medicine involve $S$. aristolochiifolia, not only in rural areas in Mexico, including indigenous land areas but also their use extends to certain cities areas of foreign countries [63]. The plant is used in the cosmetic industry to manufacture female aphrodisiac products, which merchandise in foreign countries such as the United States [64].

Besides, S. aristolochiifolia is a forest biological resource of extreme importance; for example, Totonac and Huasteca cultures take advantage of dried stems of the plant to elaborate basket back ribs and traps in the form of packing cases to catch fish $[31,65]$. On the other hand, stems and leaves of S. aristolochiifolia provide ingredients for brewing, soft drinks, and confectionery industries. The roots are the source of ingredients to aromatize beer drinks; because of their characterized bitter and sweet tastes [66].

\section{Abundance of S. aristolochiifolia}

Eighty-six percent of the whole interviewed population has a low or median abundance perception of $S$. aristolochiifolia (Table 3), according to indigenous people is due mainly by the land-use change and herbicides application on traditional production units. In the northern Sierra of Puebla, since the 60's years' in the last century, coffee plantations were expanded as a monoculture where shade and secondary vegetation types gradually replaced $41.9 \%$ of primary vegetation [67] and therefore, exacerbate the 
elimination or tolerance of wild plants such as $S$. aristolochiifolia. It is important to emphasize that the highest abundance of the plant is on acahual agroecosystems (Table 4); in the first instance, these cultivations served as pasture spaces and agriculture. With time these spaces become coffee plantations and intermediate secondary vegetation of tropical forest or mesophyll forest of the mountain [67].

Also, herbicide application mainly on the milpa agroecosystems directly impacts the presence or absence of some characteristic plants such as Quelite [68] and Kgentsililh. Despite this, milpa agroecosystems in the North Sierra of Puebla used as subsistence agriculture, use of chemical fertilizers, and occasional application of herbicides to control weeds could be influencing the low abundance of $S$. aristolochiifolia on such unit production (Table 4).

\section{The utility of prediction models}

Today, the National Information System on Biodiversity (NISB) in Mexico reported 157 collections of $S$. aristolochiifolia, five of them made by naturalists. In the literature, the State of Puebla has been describing four collects, first was on Venustiano Carranza municipality in 1960. The second on Tuzamapan de Galeana municipality in 1980, the third on Cuetzalan del Progreso municipality in 1998 [55], and the last were made by Martínez-Alfaro et al. [31] on Zapotitlán de Méndez and Xochitlán de Vicente Suárez. It means that previously have been reported the presence of Kgentsililh on five municipalities on the northern Sierra of Puebla and in this current research, we were able to georeference their growth on 22 locations and collected 32 specimens of $S$. aristolochiifolia distributed on 11 municipalities. Besides, the distribution model allows the identification of other 14 localities with a potential presence of Kgentsililh, and the distribution of this plant could include almost 25 municipalities with a total area of 303,712.2 hectares, which are a suitable habitat for $S$. aristolochiifolia.

The last statement allows the possibility to find some populations of Kgentsililh in the state of Puebla, Mexico, and according to the distribution model, it could be from 1 to a maximum of 1.85 specimens (Table 4). These analyses can then used in further biogeographic, ecological, taxonomic, conservation, and sustainable development studies for $S$. aristolochiifolia. In this respect, knowledge about the potential distribution of Kgentsililh could establish the basis by the further field specimen's collections of wild populations, which are the central source of genetic background to improve the nutritional status and yields of cash crops [69]. Also, this methodology of potential geographical distribution allows the identification of sensitive land areas exposed to climate changes in the future [70]. According to the local indigenous interviewed people in the current study, climate change is one of the main factors that influenced the relatively low abundance of $S$. aristolochiifolia, enhanced the importance to known and to identify the suitable habitat to promote in situ conservation of Kgentsililh [20].

In some regions of Mexico, such as Queretaro, the authorities argue that $S$. aristolochiifolia is a species without immediate danger of extinction but, it depends on their presence in the forest and jungle [71]. In these regions, the change of use of soil and $41.9 \%$ of natural vegetation regularly replaced monocultures and pastures until 2003 [67]. Besides, the increase of urban areas because of population growth [72] increment considerably in some degree of endangerment of Kgentsililh. Finally, on the Northern Sierra of 
the State of Puebla, several studies demonstrated the conversion of shrubby primary vegetation to primary vegetation or secondary arboreal vegetation in the last 15 years [72]. Nevertheless, the recovery of forest mass is not a good early indicator in the recovery of wild plant populations, mainly when it comes from herbs and liana such as Kgentsililh [73].

\section{Conclusions}

Smilax aristolochiifolia remains a wild species of socio-economic importance and used by the indigenous families of the Totonacapan Region Puebla. This species is consumed seasonally but still conserves a great value in food issues and traditional medicine, but it is clear that the use-value trend turns down. Besides, under this perspective, the indigenous people interviewed in our study area wait for the cause of the low abundance of Kgentsililh could be due to the next factors: changes in land use, herbicide applications, and climate change. In this sense, and according to results obtained from the potential geographical distribution area of $S$. aristolochiifolia by the Maxent Program ${ }^{\circledR}$ show us that in the Northern Sierra of the State of Puebla, there are potential areas with suitable habitat to promote in situ conservation of this native plant.

\section{Declarations}

\section{Acknowledgements}

To the indigenous families of Totonac culture of the 13 communities for their kindness answered in every interview. Also, we are deeply grateful to the collectors who accompanied us during the touring field and for the identification in situ of $S$. artisotolochiifolia.

\section{Authors contribution}

JEP coordinated the research and financed the study tours in the field for the collection of specimens of $S$. artisotolochiifolia and the interviewed applications, also contributed to the data analysis, and coordinated the writing of the manuscript. CR, JHR, and MDB contributed to the discussion of the results, review of the handwriting, and examination of the potential distribution of the species. MDB aided in the process analysis of ethnobotanical information. FRL and AEG performed the interviewed applications, preparation of the manuscript, collection, and georeferencing specimens of Kgentsililh on the field.

\section{Funding}

Does not apply

\section{Availability of data and materials}

Contact directly with the first author.

\section{Ethical approval and consent to participation}


Before this investigation, we made contact with local authorities to present the project and request authorization with a formal cover letter of every student and researcher involved in survey applications and field tours. Later, we identified the indigenous people who have known about $S$. artisotolochiifolia, and we explained specific details and objectives of the current investigation. Once we were allowed authorization by the people of the community, we began to collect ethnobotanical data, to perform field tours, and collect and take photographs of the specimens. All information presented here was obtained under prior consent and informed previously to the local authorities and residents of every community.

\section{Consent for publication}

Does not apply

\section{Consent for publication}

Authors declare that they do not have an interest in competition.

\section{Authors details}

${ }^{1}$ Posgrado en el Departamento de Agricultura, Sociedad y Ambiente. El Colegio de la Frontera Sur-Unidad San Cristóbal. San Cristóbal, Chiapas, México.

${ }^{2}$ Dirección de Investigación y Posgrado, Universidad Intercultural del Estado de Puebla, Calle Principal a Lipuntahuaca, Lipuntahuaca, Huehuetla, Puebla.

${ }^{3}$ División de Ciencias de la Vida, Universidad de Guanajuato, Carretera Irapuato-Silao, km 9, Ex Hacienda El Copal, Irapuato, Guanajuato, México

${ }^{4}$ Dirección de Ciencias Naturales, Universidad Intercultural del Estado de Puebla, Calle Principal a Lipuntahuaca, Lipuntahuaca, Huehuetla, Puebla.

\section{References}

1. Mapes C, Basurto F. Ethnobotany of Mexico. In: Lira R, Casas A, Blancas J. (eds) Ethnobotany of Mexico. Interactions of People and Plants in Mesoamerica. Springer; 2016. doi 10.1007/978-1-46146669-7.

2. Casas A, Vázquez M del C, Viveros J L, Caballero J. Plant management among the Nahua and the Mixtec in the Balsas River Basin, Mexico: An Ethnobotanical Approach to the Study of Plant Domestication. Human ecology. 1996; 24 (4): 455-478.

3. Blancas J, Casas A, Pérez-Salicrup D, Caballero J, Vega E. Ecological and socio-cultural factors influencing plant management in Nahuatl communities of the Tehuacán Valley, Mexico. Journal of Ethnobiology and Ethnomedicine. 2013; 9(39): 1-22.

4. Casas A, Caballero J. Domesticación de plantas y origen de la agricultura en Mesoamérica. CIENCIAS. 1995; 40:36-45. 
5. Hernández-Xolocotzi E. La agricultura tradicional en México. Comercio exterior. 1988; 38(8): 673-678.

6. Caballero J. La dimension culturelle de la diversité végétale au Mexique. Journal d'Agriculture Traditionnelle et de Botanique Appliqué, Nouvelle Série. 1994; 36(2): 145-158.

7. Meyfroidt P, Abeygunawardane D, Ramankutty N, Thomson A, Zeleke G. Interactions between land systems and food systems. Current opinion in Environmental Sustainability. 2019; 38:60-67.

8. van Noordwijk M, Bizard V, Wangpakapattanawong P, Tata H L, Villamor G B, Leimona B. Tree cover transitions and food security in Southeast Asia. Global Food Security. 2014; 3: 200-208.

9. Rowland D, Ickowitz A, Powell B, Nasi R, Sunderland T. Forest foods and healthy diets: quantifying the contributions. Environmental Conservation. 2017; 44(2): 102-114.

10. Arribas P, Abellán P, Velasco J, Bilton D T, Lobo J M, Millán A, Sánchez-Fernández D. La vulnerabilidad de las especies frente al cambio climático, un reto urgente para la conservación de la biodiversidad. Ecosistemas. 2012; 21(3):79-84. doi.: 10.7818/ECOS.2012.21-3.10.

11. Belz F M, Schmidt-Riediger B. Marketing strategies in the age of sustainable development: evidence from the food industry. Business Strategy and the Environment. 2010; 19:401-416.

12. Rousseau S. Food and Social Media: You Are What You Tweet. Rowman Altamira; 2012

13. Caballero J, Cortés L. Percepción, Uso y Manejo tradicional de los Recursos Vegetales en México. In: Rendon A B, Rebollar D S, Caballero N J, Martínez A M A (eds) Plantas, Cultura y Sociedad. Estudio sobre las relaciones entre seres humanos y plantas en los albores del siglo XXI. Universidad Autónoma Metropolitana; 2001.

14. Toledo V M, Barrera-Bassols N. La memoria biocultural. La importancia ecológica de las sabidurías tradicionales. ICARIA; 2009.

15. Martin G J. Etnobotánica: manual de métodos. 'Pueblos y Plantas' Manual de conservación. Editorial Nordan-Comunidad; 2001

16. Martínez-Pérez A, López P A, Gil-Muñoz A, Cuevas-Sánchez J A. Plantas silvestres útiles y prioritarias identificadas en la Mixteca Poblana, México. Acta botánica mexicana. 2012; 98: 73-98. http://www.scielo.org.mx/scielo.php?script=sci_arttext\&pid=S0187$71512012000100005 \&$ lng=es\&tlng=pt.

17. Blancas J, Casas A, Rangel-Landa S, Moreno-Calles A, Torres I, Pérez-Negró, E, Solís L, Delgado-Lemus A, Parra F, Arellanes Y, Caballero J, Cortés L, Lira R, Dávila P. Plant Management in the TehuacanCuicatlan Valley, Mexico. Economic Botany. 2010; 64(4): 287-302. doi: 10.1007/978-1-4614-6669-7.

18. Casas A, Blancas J, Lira R. Mexican Ethnobotany: Interactions of people and plants in Mesoamerica. In: Lira R, Casas A, Blancas J. (eds) Ethnobotany of Mexico. Interactions of People and Plants in Mesoamerica. Springer; 2016. doi 10.1007/978-1-4614-6669-7.

19. Siqueira M F D, Durigan G. Modelagem da distribuição geográfica de espécies lenhosas de cerrado no Estado de São Paulo. Revista Brasileira de Botânica. 2007; 30(2): 233-243.

20. De Marco Júnior P, Siqueira M F. Como determinar a distribuição potencial de espécies sob uma abordagem conservacionista. Megadiversidade. 2009; 5: 65-76. 
21. Rezende V L, de Oliveira-Filho A T, Eisenlohr P V, Kamino L H Y, Vibrans A C. Restricted geographic distribution of tree species calls for urgent conservation efforts in the Subtropical Atlantic Forest. Biodiversity and Conservation. 2014; 24: 1057-1071. https://doi.org/10.1007/s10531-014-0721-7.

22. Villaseñor J L, Téllez-Valdés. Distribución potencial de las especies del género Jefea (Asteraceae) en México. Anales del Instituto de Biología. Serie Botánica. 2004; 75 (2): 205-220. https://www.redalyc.org/articulo.oa?id=400/40075203.

23. Delgado-Lemus A, Torres I, Blancas J, Casas A. Vulnerability and risk management of Agave species in the Tehuacán Valley, México. Journal of Ethnobiology and Ethnomedicine. 2014; 10 (53). doi: 10.1186/1746-4269-10-53.

24. Perosa M, Rojas J F, Villagra P E, Tognelli M F, Carrara R, Álvarez J A. Distribución potencial de los bosques de Prosopis flexuosa en la Provincia Biogeográfica del Monte, desde Catamarca hasta Mendoza (Argentina). Ecología Austral. 2014; 24: 238-248.

25. Hernández-Ruíz J, Herrera-Cabrera B E, Delgado-Alvarado A, Salazar-Rojas V M, Bustamante-González Á, Campos-Contreras J E, Ramírez-Juárez J. Distribución potencial y características geográficas de poblaciones silvestres de Vanilla planifolia (Orchidaceae) en Oaxaca, México. Revista de Biología Tropical. 2016; 64(1), 251-262 https://www.redalyc.org/articulo.oa?id=449/44943437021.

26. Espinosa-Trujillo E, Gámez V A J, Avila P M A, Palemón A F, Hernández-Ruíz J. Distribución geográfica potencial de papaya silvestre cultivada en México. Revista Mexicana de Ciencias Agrícolas. 2018; 9(7):1377-1388. https://cienciasagricolas.inifap.gob.mx/index.php/v9n7-005.

27. Scheldeman X, van Zonneveld M. Training Manual on Spatial Analysis of Plant Diversity and Distribution. Bioversity International. 2010. http://www.bioversityinternational.org/index.php? id=19\&user_bioversitypublications_pi1[showUid]=5052 Accessed in 2020.

28. Merow C, Allen J M, Aiello L M, Silander J A. Improving niche and range estimates with Maxent and point process models by integrating spatially explicit information. Global Ecological Biogeography. 2016; 25:1022-1036.

29. Pérez-Najera V C, Gutierrez-Uribe J A, Antunes-Ricardo M, Hidalgo-Figueroa S, Del-Toro-Sánchez C L, Salazar-Olivo L A, Lugo-Cervantes E. Smilax Aristolochiifolia root extract and its compounds chlorogenic acid and astilbin inhibit the activity of of $\alpha$-Amylase and $\alpha$-Glucosidase Enzymes. Evidence-Based Complementary and Alternative Medicine. 2018; 1-12. https://doi.org/10.1155/2018/6247306.

30. Martínez M A, Evangelista V, Basurto F, Mendoza M, Cruz-Rivas A. Flora útil de la Sierra Norte de Puebla, México. Revista Mexicana de Biodiversidad. 2007; 78(1): 15-40.

31. Martínez-Alfaro M A, Evangelista O V, Mendoza C M, Morales G G, Toledo O G, Wong L A. Catálogo de plantas útiles de la Sierra Norte de Puebla, México. Cuadernos 27. Instituto de Biología, Universidad Nacional Autónoma de México; 1995.

32. Ferrufino-Acosta L. Taxonomic revision of the genus Smilax (Smilacaceae) in Central America and the Caribbean Islands. Willdenowia. 2010; 40(2): 227-280. https://doi.org/10.3372/wi.40.40208 
33. Amaro C A B, González-Cortazar M, Herrera-Ruiz M, Román-Ramos R, Aguilar-Santamaría L, Tortoriello J, Jiménez-Ferrer E. Hypoglycemic and Hypotensive Activity of a Root Extract of Smilax aristolochiifolia, Standardized on N-trans-Feruloyl-Tyramine. Molecules. 2014; 19, 11366-11384.

34. Qi Z, Li P, Zhao Y, Cameron K M, Fu C. Molecular phylogeny and biogeography of Smilacaceae (Liliales), a cosmopolitan family of monocots. Botanical Journal of the Linnean Society. 2013; 173: 535-548. http://www.2012.botanyconference.org/engine/search/index.php?func=detail\&aid=441.

35. Li P. A taxonomic revision of Smilacaceae in Asia and phylogeography of North American herbaceous Smilax. 2012. Unpublished Doctor Phil. Thesis, Zhejiang University

36. Govaerts R. World checklist of Smilacaceae. Kew: Facilitated by the Royal Botanic Gardens. 2019; http://apps.kew.org/wcsp/ Accessed in 2020.

37. Challinor V L, Parsons P G, Chap S, White E F, Blanchfield J T, Lehmann R P, De Voss J J. Steroidal saponins from the roots of Smilax sp.: Structure and bioactivity. Steroids. 2012; 77 (5): 504-511. https://doi.org/10.1016/j.steroids.2012.01.009

38. Villaseñor J L. Los géneros de plantas vasculares de la Flora en México. Boletín de la Sociedad Botánica de México. 2004; 75:105-135. doi: 10.17129/botsci.1694

39. Morton C V. A reexamination of Mexican Smilax (Smilacaceae). Britonia. 1962; 14: 299-309.

40. Ruíz-Sánchez E, Castro-Castro A, Clark L G. Chusquea septentrionalis sp. nov. (Poaceae: Bambusoideae) from the Madrean region in Durango, Mexico. Nordic Journal of Botany. 2017; 1-6. doi: 10.1111/njb.01606

41. Masferrer K E. Los dueños del tiempo. Los tutunakú (Totonacos) de la Sierra Norte de Puebla. Lito nueva época; 2005.

42. Argueta A, Mapes C, Villers L, et al. Etnobotánica y uso diferenciado en una región Cálido-Húmedo de la Sierra Norte de Puebla. In: Aguilar A, Argueta A, Mapes C. (coord) Miguel Ángel Martínez Alfaro y la Etnobotánica Mexicana del siglo XXI. Universidad Nacional Autónoma de México; 2009.

43. Mapes C, Basurto F, Bye R. Ethnobotany of Quintonil: Knowledge, Use and Management of edible greens Amaranthus spp. (Amaranthaceae) in the Sierra Norte de Puebla, Mexico. Economic Botany. 1997; 51(3): 293-306.

44. Basurto-Peña F, Castro D, Martínez M A. Edible begonias from the north of Puebla, México. Economic Botany. 2003; 57(1): 48-53

45. Pagaza C M E. El desplazamiento cultural y su influencia en los huertos familiares de la Sierra Norte de Puebla. In: Ramírez V B, Bernal M H. (eds) Investigación Multidisciplinaria en la Sierra Norte de Puebla. Colegio de Postgraduados; 2009.

46. Espinoza-Pérez J. Caracterización de huertos familiares tradicionales en Ozelonacaxtla, Huehuetla, Puebla. Bachelor thesis. Universidad Intercultural del Estado de Puebla. Puebla, México. 2013. https://www.researchgate.net/publication/290996198 Accessed on 2020.

47. Ángel-Pérez A L D, Alfonso M B M. Totonac homegardens and natural resources in Veracruz, Mexico. Agriculture and Human Values. 2004; 21: 329-346. 
48. Espinoza-Pérez J, García N H B. Recursos naturales y su relación con la comunidad. In: Hernández L S, Lemus de J G L, (eds) El territorio de San Juan Ozelonacaxtla. Uso y cuidado desde la cosmovisión Totonaca. Universidad Intercultural del Estado de Puebla; 2017.

49. Phillips O, Gentry A H. The useful plants of Tambopata, Peru: I. Statistical Hypothesis Tests with a new quantitative technique. Economic Botany. 1993; 47(1):15-32.

50. Phillips S J, Dudík M, Schapire R E. Maxent software for modeling species niches and distributions (Version 3.4.1). http://biodiversityinformatics.amnh.org/open_source/maxent/ Accessed in 2020.

51. Mbatudde M, Mwanjololo M, Kakudidi E K, Dalitz H. Modelling the potential distribution of endangered Prunus africana (Hook. f.) Kalkm in East Africa. African Journal of Ecology. 2012; 50(4), 393-403. http://doi.org/10.1111/j.1365-2028.2012.01327.x.

52. Continuo de Elevaciones Mexicano (CEM). https://www.inegi.org.mx/app/geo2/elevacionesmex. Accessed in 2019.

53. CONABIO. Comisión Nacional para el Conocimiento y Uso de la Biodiversidad (CONABIO). Uso de suelo y vegetación. Escala 1:1.000 000. 1998; Modificado de: Instituto Nacional de Estadística, Geografía e Informática (INEGI), Instituto Nacional de Ecología (INE). 1996; Uso del suelo y vegetación, escala 1:1.000 000. México.

http://www.conabio.gob.mx/informacion/metadata/gis/usva1mgw.xml?-httpcache=yes\&$\mathrm{xsl}=/ \mathrm{db} /$ metadata/xsl/fgdc-html.xsl\&-indent=no. Accessed in 2019.

54. Maples-Vermeersch M. Regímenes de humedad del suelo en Hidrogeografía IV.6.2 Atlas Nacional de México. Vol. II. Escala 1:4000000. Instituto de Geografía, UNAM. México. 1992. http:// www.conabio.gob.mx/informacion/metadata/gis /rehsu4mgw.xml? _httpcache=yes\&_xsl=/db/metadata/xsl/fgdc_html.xsl\&_indent=no. Accessed in 2019

55. Enciclovida. Comisión Nacional para el Conocimiento y Uso de la Biodiversidad. http://enciclovida.mx/especies/160880-smilax-aristolochiifolia. Acces in 2020.

56. Bertrán V M. Cambio alimentario e identidad de los indígenas Mexicanos. Dirección General de Publicaciones y Fomento Editorial. Universidad Nacional Autónoma de México; 2005.

57. Martínez-Alfaro M A. Medicinal plants used in a Totonac community of the Sierra Norte de Puebla: Tuzamapan de Galeana, Puebla, Mexico. Journal of Ethnopharmacology. 1984; 11:203-221.

58. Fernández N R, Ramos Z D, Carranza G E. Notas sobre plantas medicinales del estado de Querétaro, México. Polibotánica. 2001; 12: 1-39.

59. Alonso-Castro A J, Domínguez F, Zapata-Morales J R, Carranza-Álvarez C. Plants used in the traditional medicine of Mesoamerica (Mexico and Central America) and the Carribbean for the treatment of obesity. Journal of Ethnopharmacology. 2015; 175: 335-345.

http://dx.doi.org/10.1016/j.jep.2015.09.029.

60. Carrillo A M. From badge of pride to cause of stigma: combatting mal del pinto in Mexico. Endeavour. 2013; 37(1):13-20. http://dx.doi.org/10.1016/j.endeavour.2012.11.005.

61. Aguilar A, Camacho J R, Chino S, Jáquez P, López M E. Herbario Medicinal del Instituto Mexicano del Seguro Social. Instituto Mexicano del Seguro Social. Información Etnobotánica; 1994. 
62. Andrade-Cetto A, Heinrich M. Mexican plants with hypoglycemic effect used in the treatment of diabetes. Journal of Ethnopharmacology. 2005; 99: 325-348. doi:10.1016/j.jep.2005.04.019.

63. Ladio A H, Acosta M. Urban medicinal plant use: Do migrant and non-migrant populations have similar hybridisation processes? Journal of Ethnopharmacology. 2019; 234: 290-35. https://doi.org/10.1016/j.jep.2019.01.013.

64. Prescott H, Khan I. Medicinal plants/herbal supplements as female aphrodisiacs: Does any evidence exist to support their inclusion or potencial in the treatment of FSD? Journal of Ethnopharmacology. 2020; 251: 112464. https://doi.org/10.1016/j.jep.2019.112464.

65. Alcorn J B. Development policy, forests, anda peasant farms: Reflections on Huastec-managed forest 'contributions to commercial production and resource conservation. Economic Botany. 1984; 38 (4): 389-406.

66. Seidemann J. World Spice Plants. Springer-Verlag; 2005.

67. Evangelista O V, López B J, Caballero N J, Martínez-Alfaro M A. Patrones espaciales de cambio de cobertura y uso del suelo en el área cafetalera de la sierra norte de Puebla. Investigaciones geográficas. 2010; (72), 23-38. http://www.scielo.org.mx/scielo.php?script=sci_arttext\&pid=S0188$46112010000200003 \&$ lng =es\&tlng=es.

68. Mascorro-de Loera R D, Ferguson B G, Perales-Rivera H P, Charbonnier F. Herbicidas en la milpa: Estrategias de aplicación y su impacto sobre el consumo de arvenses. Ecosistemas y Recursos Agropecuarios. 2019; 6(18): 477-486. http://dx.doi.org/10.19136/era.a6n18.2076

69. Rodríguez C J, Díaz H Y, Pérez G A, Natali C Z, Rodríguez H P. Evaluación de la calidad y el rendimiento en papaya silvestre (Carica papaya L.) de Cuba. Cultivos Tropicales. 2014; 35(3):36-44.

70. Gutiérrez E, Trejo I. Efecto del cambio climático en la distribución potencial de cinco especies arbóreas de bosque templado en México. Revista Mexicana de Biodiversidad. 2014; 85: 179-188. doi: http://dx.doi.org/10.7550/rmb.37737.

71. Calderon G, Rzedowsky J. Flora del bajío y regiones adyancentes. Fascíbulo 26. 1994. http://inecolbajio.inecol.mx/floradelbajio/documentos/fasciculos/ordinarios/Smilacaceae\%2026.pdf. Acces in 2020.

72. Guevara R M L, Montalvo V R. Changig land use and vegetation arising from the provision of infraestructura: In the Sierra north of Puebla. Revista Eleactrónica Nova Scientia. 2014; 13 (7): 314336. http://www.scielo.org.mx/pdf/ns/v7n13/v7n13a17.pdf

73. Brenes-Chaves L, Méndez-Cartín A L, Sánchez-Toruño H, Montero-Flores W, Barquero-Elizondo A I, Hernñandez-Sánchez L G. Structure and composition of a secondary forest in the Ostional National Wildlife Refuge, Guanacaste, Costa Rica. Revista Forestal Mesoamericana. 2019; 16(39): 33-42. doi: $10.18845 /$ rfmk.v16i39.4417

\section{Figures}



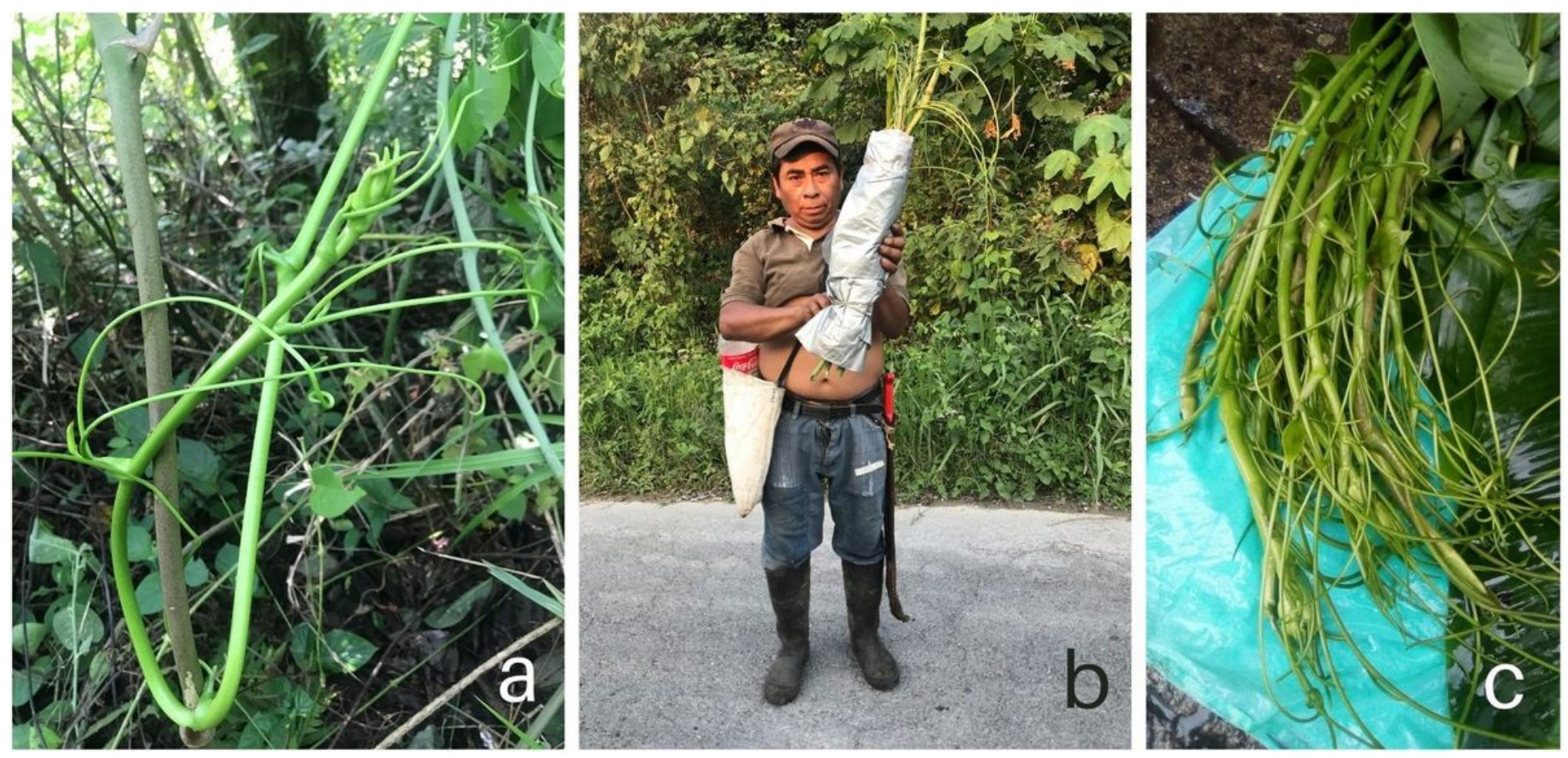

Figure 1

Collection and sale of S. aristolochiifolia in the northern Sierra of Puebla

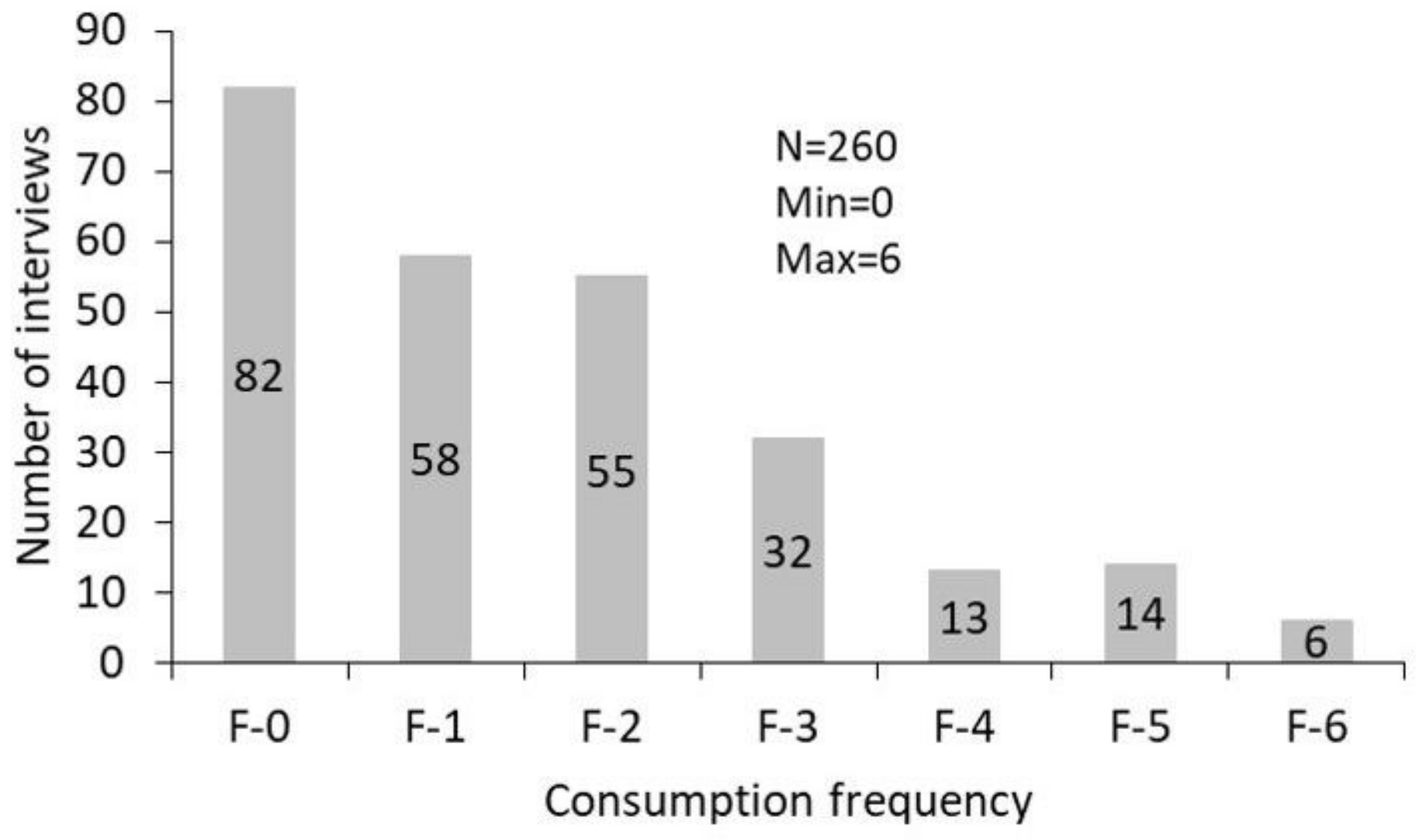

Figure 2 
Consumption frequency of $\mathrm{S}$. aristolochiifolia in the Totonacapan Puebla region. $(\mathrm{F}-0)=$ does not consume; $(\mathrm{F}-1)=$ consume at least once a year; $(\mathrm{F}-2)=$ consume twice a year; $(\mathrm{F}-3)=$ consume three times a year; $(\mathrm{F}-$ $4)=$ consume four times a year; $(F-5)=$ consume five times a year; $(F-6)=$ consume six times a year.
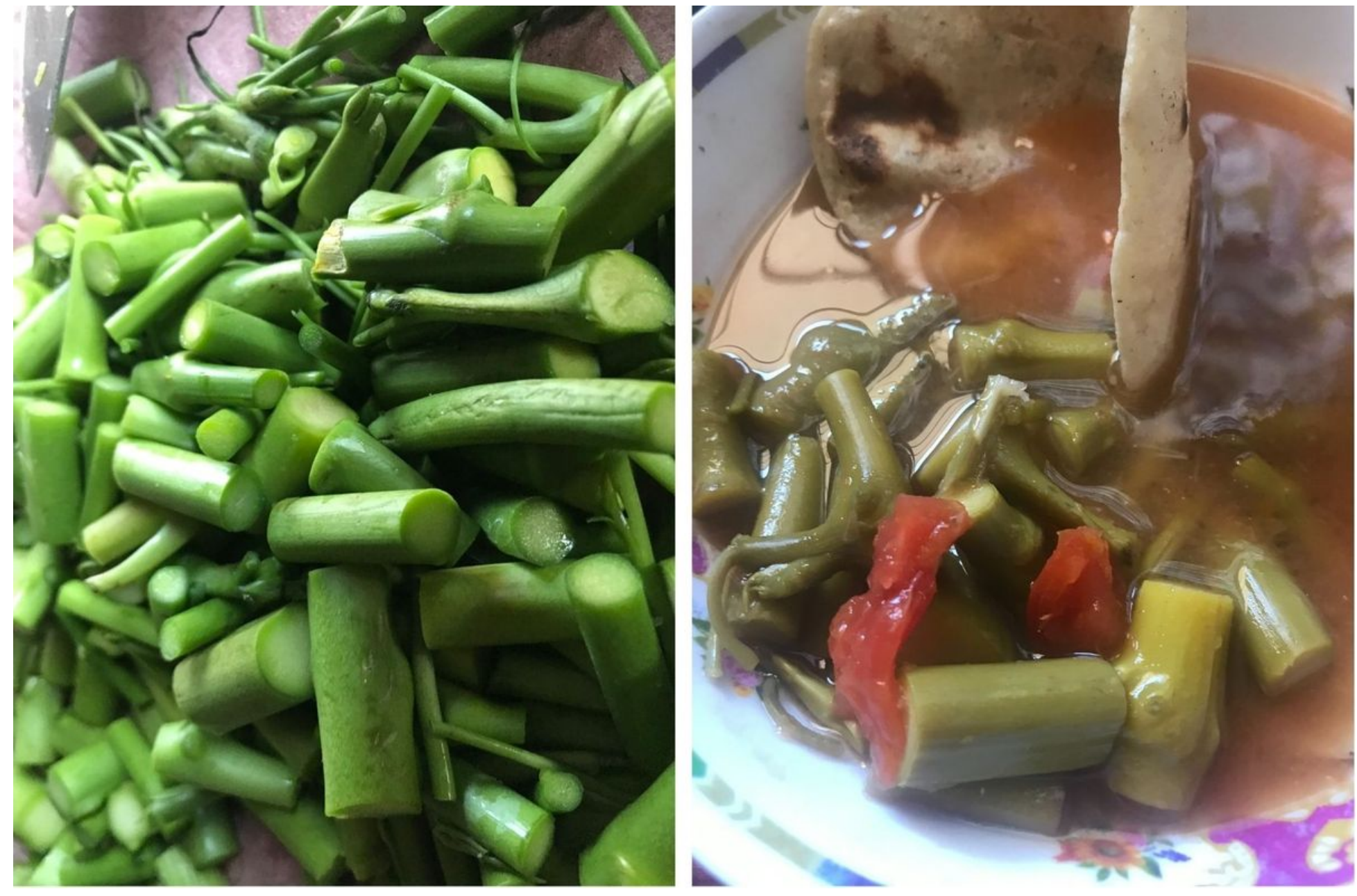

Figure 3

Totonaco recipes with Smilax aristolochiifolia 


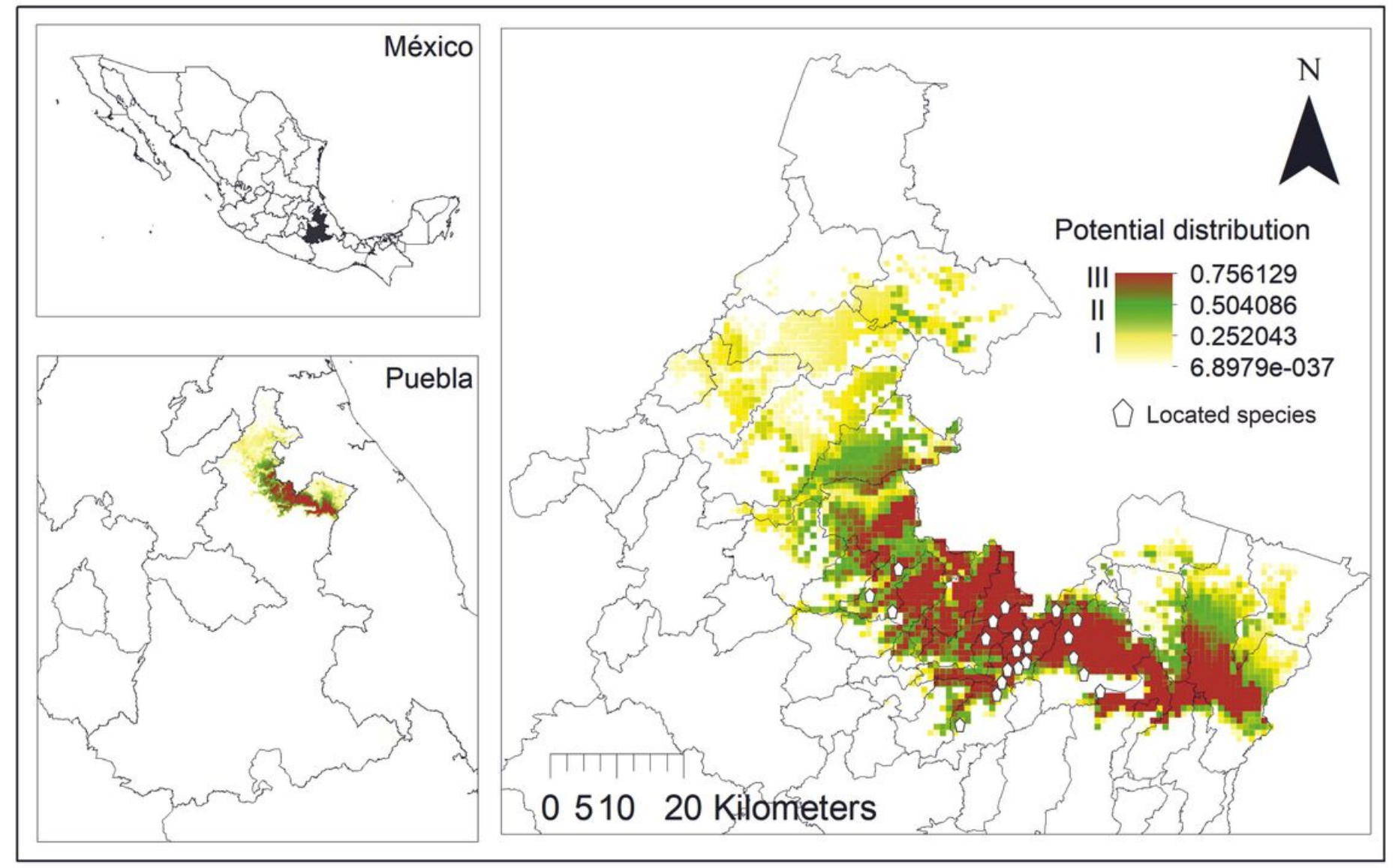

Figure 4

Potential geographical distribution of S. aristolochiifolia in the State of Puebla. Note: The designations employed and the presentation of the material on this map do not imply the expression of any opinion whatsoever on the part of Research Square concerning the legal status of any country, territory, city or area or of its authorities, or concerning the delimitation of its frontiers or boundaries. This map has been provided by the authors. 

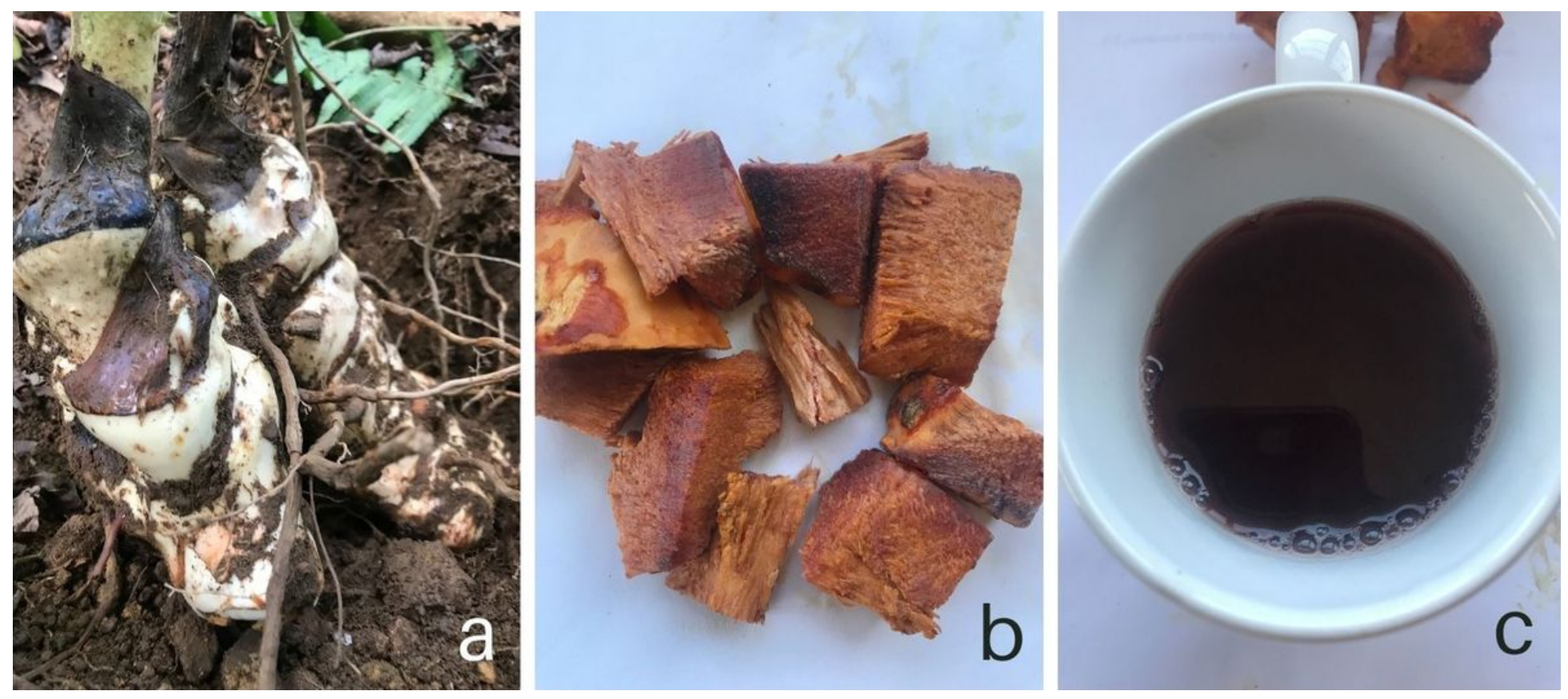

\section{Figure 5}

Procedure for oral infusion preparation of S. aristolochiifolia. (a) Sweet potato extraction (b) trituration, washing, and drying of sweet potato (c), tea infusion preparation.

\section{Supplementary Files}

This is a list of supplementary files associated with this preprint. Click to download.

- LetterofPresentation.pdf

- ProodofCulturalldentity.pdf

- SitesofpotentialdistributionofSmilaxaristolochiifolia.xlsx 